\title{
The Study of Agribusiness Market Development in Jember Regency
}

\author{
$1^{\text {st }}$ Budi Hariono \\ Agriculture Technology \\ State Polytechnic of Jember \\ Jember, Indonesia \\ budihariono1966@gmail.com
$4^{\text {th }}$ Mokhamad Fatoni Kurnianto
Agriculture Technology
Politeknik Negeri Jember
Jember, Indonesia
ftnpolije@gmail.com

\author{
$2^{\text {nd }}$ Rizza Wijaya \\ Agriculture Technology \\ State Polytechnic of Jember \\ Jember, Indonesia \\ rizza.wijaya@polije.ac.id
}

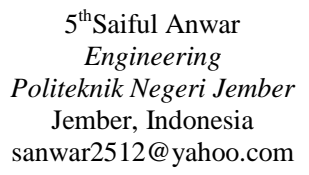

\author{
$3^{\text {rd }}$ Dyah Laksito Rukmi \\ Animal Husbandry \\ State Polytechnic of Jember \\ Jember, Indonesia \\ dyah.laksito@polije.ac.id
}

\begin{abstract}
Jember Regency is one of the agropolitan center areas in East Java. The abundance production of plantation, livestock, and fishery as the agribusiness opportunities cannot be enjoyed maximally by the farmers, especially for those who live in the countryside. The long marketing channel makes the farmers to have no choice, so that they sell their crops to the traders and other busnissemen. The government of Jember Regency through the institutional approach tries to do a rural economy restructurisation through an Agribusiness Market development program. Regional approach with factorial analysis was used in this research to structure the complex problem by making the priority sequence of problems and the solutions in choosing a location which involved the participatory of all relevant stakeholders. The choice of an ideal location was a way to accommodate the parties' interests, various tactical-strategic objectives by considering several factors. Based on the sucsess determinant of the goal achievement, the following were the priority sequence of Agribusiness Market locations in Jember Regency: Bangsalsari District, Ajung Districts, Rambipuji District, and Gumukmas District.
\end{abstract}

Keywords-Jember Regency; Agribusiness Market; and Selection of Agribusiness Market Location.

\section{INTRODUCTION}

Jember Regency is located in the eastern part of East Java Province. The location is very strategic, because it is traversed by the SurabayaBanyuwangi primary artery road. The total area of Jember Regency is 3,293.34 $\mathrm{Km}^{2}$, with large fertile plain area which is utilized as agricultural land for food crops and plantation with the commodities of tea, coffee, cacao, rubber, tobacco, sugar cane, and coconut. Based on the agricultural nature which relies on biological process by utilizing the natural resources in the rural area, so that the implementation of the business development must be done through the agribusiness approach system which is in line with the rural economy restructurisation[1].

The agribusiness activity which gets along with the rural economy restructurisation needs a support facilitate to enhance the marketing activity of agricultural, fishery, and plantation products. Marketing includes the problem which happens at the farmer level covering the length of trade chain that causes the lower income earned by the farmers, because it is enjoyed only by the traders and other agribusiness actors.

Several efforts has been done to cope this problem, either through internal sectoral program or by autonomous local economic empowerment activity based on regional policies. One of the things that has been done by Jember Regency Government related to agribusiness activities in producer level is by marketing activity of plantation commodities through an institutional approach that is Agribusiness Market [2].

The Agribusiness Market basically is a market where the transaction activity of plantation products (holticultural, livestock, and fishery) from the producer to the trader in the modern market which is completed with the product quality, information system, promotion, sorting, grading, and packing, exporter are then distributed to the consument. The existence of Agribusiness Market is expected to be the center of business transaction which can increase the farmer's living standard. Besides, it can also shorten the marketing chain because the wholesaler eventually becomes ordinary trader and the function of Agribusiness Market will constinuously develop with its prinsciples, if only the supporting facilities and infrastructures covering the surrounding society, farmers, and related instituions both government 
and private are available. The Agribusiness Market continuously experiences the development and reformation to be a marketing institution which supports the farmer in marketing their agricultural products.

Based on that approach, an Agribusiness Market Development study in Jember Regency was formulated. The objective of this research was to get information about the right and accurate pattern to develop the area potential optimally through productive activities in order to improve the regional economy and income. The basic strategy to achieve the objective above was by the society agricultural transformation process through the Agribusiness Development Unit (UPA) which was united into Agribusiness Market. There are many alternative strategies to develop industry in Jember Regency and the priority strategy is to optimize the role of agribusiness subsystem [3].

Agribusiness Market is a place for buying and selling transactions between producer and trader of agricultural commodities. The implementing concept of Agribusiness Market is to be a center of selling and buying transactions which is comfortable for the various and large volume of agricultural commodities with competitive prices. Agricultural Market enlarges the marketing opportunity of agricultural products as well as facilitate the distribution channel either for domestic or foreign, so that the fresh or processed commodities are guaranteed qualities. Therefore, the farmers and agribusiness actors in Jember Regency can get a positive benefit from the existence of Agricultural Market since they can increase their income through the natural resources based productive activity either direct or indirect involvement through the Agricultural Market facility.

\section{ReSEARCH Methodology}

Based on the dimension and the scope of area, the Agricultural Market development which is operational and applicable must use the regional approach. The basic concept of Agricultural Market development covers 3 stages that are preparation, planning, and implementation (Fig 1).

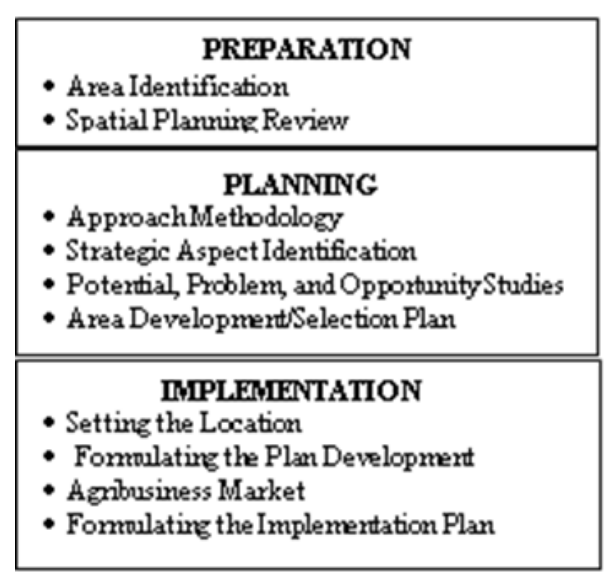

Fig 1. The Stages of Agribusiness Market Development

The methodology developed in this research was comprehensive approach which included 6 basic elements, as follows:

- Integrated regional based

- Regional potential commodity based

- Oriented to increase the society income

- Multi-stakeholders business partnerships based

- Holistic and sustainable

- Formal legal institutionally

\section{A. Research Context}

The study of Agribusiness Market in Jember Regency was administered in each area of all districts in Jember Regency.

\section{B. Data Collection Method}

The data collected in this research consisted of primary and secondary data. The primary data were obtained from field observation and in-depth interview with the experts, while the secondary data were collected through literature study with desk research method [4].

\section{Analysis Methodology}

- Factor Analysis

Factor analysis is an analysis that is used to classify the similar variables related to the development key of Agribusiness Market. The purpose of factor analysis was to summarize the information containing the potential variable at the initial step into several variables to be included in the next analysis. The use of this analysis tool was to group the similar variables related to the key factor that must be concerned in the Agribusiness Market development. To use this analysis tool in its implementation was by exploring all potential factors first into key success factors. In short, the 
steps in the factor analysis was shown in the Fig 2 [5].

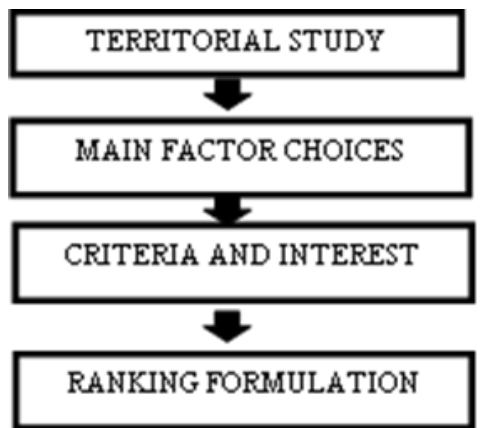

Fig 2. Analytic Hierarchy Process (AHP)

Analytic hierarchy process is a problem solving method by structuring a complex problem by making a priority problem sequence and a solution to choose a location which involves all related stakeholders participatively. Every hierarchy consists of some components which can be explained into more specific sub-components [6].

This decomposition process can be continued until a controlled or operational component is found. This method can be used to find the importance of each activity structure or hierarchy criteria, so that we can find the importance of each element in each hierarchy level [7].

Here are the stages of Analytic Hierarchy Process in solving a problem [8]:

a) Stage 1: Defining the problem and determining the solution according to the objective.

b) Stage 2: Formulating the hierarchy structure which starts with the general objective, then continued by the following sub-objectives, criteria, and the possibility of the lowest hierarchy or simply is to determine the whole objective and then continued with intermediary hierarchies so that it can be achieved the level in which the component/element is able to be controlled or it might be able to solve the problem.

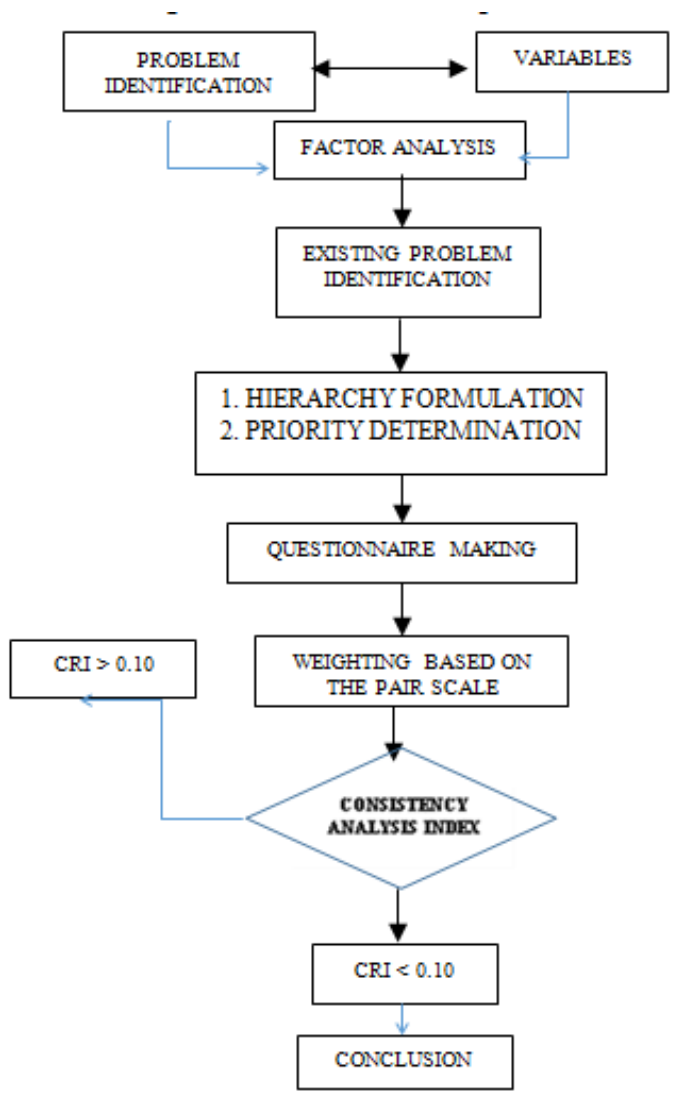

Fig 3. The Stages of Analytic Hierarchy Process

c) Stage 3: Creating a pair comparison matrix which has a relative contribution or influence in each element of each objective or criteria which is developed at a higher level. A pair comparison done with judgement from decision maker by determining the level of importance of an element/component against other component.

d) Stage 4: Performing a pair comparison to find the total judgment as much as [n (n-1)/2] pieces, in which $\mathrm{n}$ : the number of compared components.

e) Stage 5: Calculating the Eigen value and testing its consistency, if the consistency value is greater than $10 \%$, then the process of collecting data must be repeated.

f) Stage 6: Repeating the stages 3, 4, and 5 for all hierarchy levels.

g) Stage 7: Calculating the Eigen vector for all pair comparison matrix, the Eigen value is the weight of each element. This stage is a synthesizing judgement to determine the priority elements at the lowest hierarchy level towards the objective achievement.

h) Stage 8: Checking the hierarchy consistency, if the consistency value is lower or equal to $10 \%$ it means that the hierarchy is already consistent and fulfills the requirement.

i) Stage 9: Determining the policy choices which is in line with the produced agreement. 
j) Stage 10: Simulation - Policy Development and preparation of the agroforest system management strategy.

\section{RESULTS AND DISCUSSION}

Agribusiness Market was a part of the city structure activities which evoked the economy revival in Jember Regency. The selection factor of market location was an absolute requirement for the implementation of agribusiness activity. The following were the selection stages that must be fulfilled by the prospective location of agribusiness market:

\section{A. Determination of the Beginning Location of Agribusiness Market}

\section{1) The selection factor of rice production}

For the selection factor of rice production, the score was given by dividing the highest rice production with the highest assumption value. The highest rice production was in Sumberbaru District that was 530410 quintal $(530410 / 5=106082)$. Therefore for:

- 0 - 106802 quintal, got score 1 with a weight of 2

- 106802 - 212164 quintal, got score 2 with a weight of 4

- $212164-318246$ quintal, got score 3 with a weight of 6

- 318246 - 424328 quintal, got score 4 with a weight of 8

- 424328 - 530410 quintal, got score 5 with a weight of 10

2) The selection factor of the road network

For the selection factor of the road network, the road assessment was seen from the National road to Village road.

- National road got score 5 with a weight of 10

- $\quad$ Province road got score 4 with a weight of 8

- Regency road got score 3 with a weight of 6

- District road got score 2 with a weight of 4

- Rural road got score 1 with a weight of 2

\section{3) The selection factor of Population}

The assessment was given by dividing the highest number of the population with the highest assumption value. The highest number of population was in Balangsari District as much as 107632 people.

$107632 / 5=21526$. Thus, for:

- $\quad 0-21526$ people got score 1 with a weight of 2
- 21526 - 43053 people got score 2 with a weight of 4

- 43053 - 64579 people got score 3 with a weight of 6

- 64579 - 86106 people got score 4 with a weight of 8

- 86106 - 107632 people got score 5 with a weight of 10

\section{4) The selection factor of slope}

The assessment was given by dividing the highest land slope which was $<8 \%$ with the highest assumption value. For the land slope which was $<2 \%$ was in Ambulu District 9223 ha.

- 0 - 1845 ha got score 1 with a weight of 2

- 1845- 3689 ha got score 2 with a weight of 4

- $\quad 3689-5534$ ha got score 3 with a weight of 6

- 5534- 7378 ha got score 4 with a weight of 8

- 7378-9223ha got score 5 with a weight of 10

\section{5) The selection factor of distance to the city}

Rating was given by dividing the highest distance to the city center with the highest assumed value. The farthest distance to the city center was Kencong District $50 \mathrm{Km}$.

$50 / 5=10$. So for:

- $\quad 0-10 \mathrm{~km}$, got score 5 with a weight of 10

- $10-20 \mathrm{~km}$, got a value 4 with a weight of 8

- $20-30 \mathrm{~km}$, score 3 with a weight of 6

- $\quad 30-40 \mathrm{~km} 2$ with a weight of 4

- $40-50 \mathrm{~km}$, got score 1 with a weight of 2

The initial analysis result informed that there were 4 (four) districts that had the highest score as an alternative choice for agribusiness location. Then the analysis by using AHP Method was carried out to select and re-rank the four locations, adjusted to the 'compromise' of various interests of the whole stakeholder component.

\section{B. The Choice Analysis of Agribusiness Market Location}

The location choice was very determined by the preferences of each stakeholder (those who had both direct and indirect interests) in the region. The approach method used was the Analysis Hierarchy Process (AHP), the expected result was that the chosen location was the best choice that accommodated the interests of various parties, various tactical-strategic objectives, by taking into account various factors, so that the "ideal" location was chosen.

In this case, the stakeholders identification in the development of Agribusiness Market in Jember Regency, including: The Regency Planning and Development Agency, The Regional People's Legislative Assembly, Agricultural Department, 
Transportation Department, Market Department, producer farmers, agro merchant groups, nongovernmental organization of agricultur, academics, investors, customer/consumer.

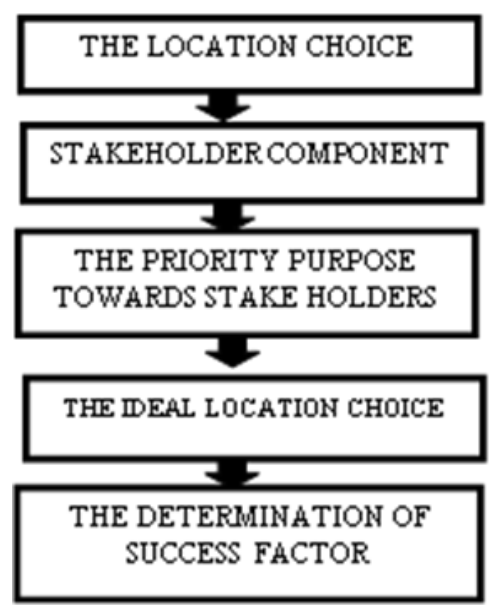

Fig 4. The Location Choice Structure with AHP Method

The component of the development objectives of the Agribusiness Market was the priority of direct and indirect interests of every stakeholder, including: increasing the local revenue, regional development, attracting investors in the agribusiness field, developing regional potential, providing employment opportunities, farmers' welfare, consumer convenience, encouraging backward-forward linkages. The success determinants of achieving the Agribusiness Market development objectives above, would depend on several key factors, including aspects: conducive local regulations, technology readiness, human resources, number and types of superior products, competitive market value, facilities completeness, management systems, future prospects, security, comfort and transportation. With the AHP method it was determined:

1. Based on the stakeholders preferences, in appreciating the Agribusiness Market development objectives, obtained the order of priority objectives as follow:

TABLE I. THE ORDER OF PRIORITY OBJECTIVES

\begin{tabular}{|c|l|c|}
\hline No. & \multicolumn{1}{|c|}{ Priority Objective } & Weight \\
\hline 1 & $\begin{array}{l}\text { Improving the quality and the } \\
\text { productivity of the agricultural } \\
\text { products }\end{array}$ & $29,40 \%$ \\
\hline 2 & Regional potential Development & $14,59 \%$ \\
\hline 3 & Farmer welfare & $14,18 \%$ \\
\hline 4 & Consumer's convenience & $11,80 \%$ \\
\hline 5 & Regional economic development & $9,34 \%$ \\
\hline 6 & Attracting investors in agribusiness & $7,43 \%$ \\
\hline 7 & Providing employment opportunities & $6,69 \%$ \\
\hline 8 & $\begin{array}{l}\text { Encouraging backward-forward } \\
\text { linkages }\end{array}$ & $6,58 \%$ \\
\hline
\end{tabular}

2. Based on the Agribusiness Market development objectives preferences, obtained the following factors priority order of as follow:

TABLE II. THE FACTORS PRIORITY ORDER

\begin{tabular}{|c|l|c|}
\hline No. & \multicolumn{1}{|c|}{ Priority Factor } & Weight \\
\hline 1 & $\begin{array}{l}\text { Local regulations that support PA } \\
\text { policies }\end{array}$ & $20,27 \%$ \\
\hline 2 & Completeness of PA Facilities & $17,7 \%$ \\
\hline 3 & $\begin{array}{l}\text { Compliance with regional } \\
\text { development plans (RTRW) }\end{array}$ & $11,34 \%$ \\
\hline 4 & Human resource readiness (HR) & $10,60 \%$ \\
\hline 5 & $\begin{array}{l}\text { Prospects for Sustainability of } \\
\text { Agribusiness Market (PA) }\end{array}$ & $8,66 \%$ \\
\hline 6 & Superior product type & $8,47 \%$ \\
\hline 7 & Security & $7,03 \%$ \\
\hline 8 & Proximity of public facilities & $5,43 \%$ \\
\hline 9 & Area & $4,09 \%$ \\
\hline 10 & Transportation & $3,49 \%$ \\
\hline 11 & Comfort & $3,34 \%$ \\
\hline
\end{tabular}

3. Based on the success determinants of achieving the objectives, the following order of priority was obtained:

TABLE III. THE SUCCESS DETERMINANTS OF ACHIEVING OBJECTIVES

\begin{tabular}{|c|l|c|}
\hline No. & \multicolumn{1}{|c|}{ Location } & Weight \\
\hline 1 & Bangsalsari & $47,93 \%$ \\
\hline 2 & Ajung & $22,11 \%$ \\
\hline 3 & Rambipuji & $15,50 \%$ \\
\hline 4 & Gumukmas & $14,45 \%$ \\
\hline
\end{tabular}

Based on the priority result attached to the table above, the result thatplotted in a map can be seen in Fig 5.

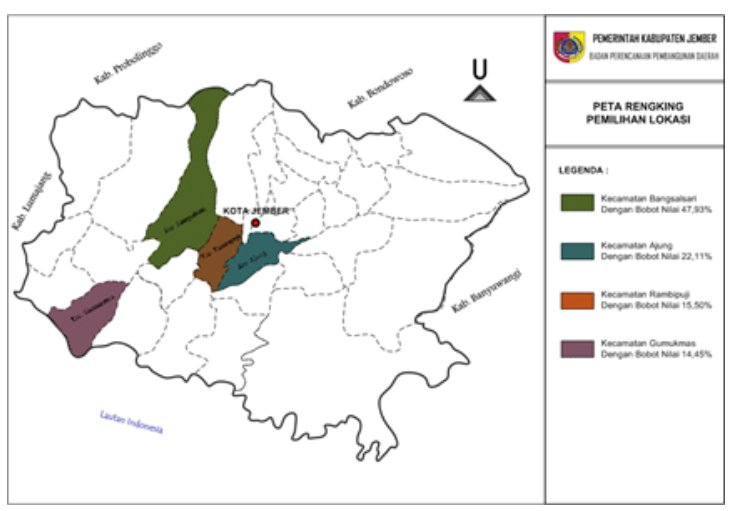

Fig 5. The Determinants Map of Location Order

\section{CONCLUSION}


The ideal location selection was a way to accommodate the interests of various parties, various tactical-strategic objectives, by taking into account various factors. Based on the success determinants of the objectives achievement, the priority order of the area of Agribusiness Market Development in Jember Regency including: 1). Bangsalsari District, 2). Ajung District, 3). Rambipuji District, and 4). Gumukmas District.

\section{ACKNOWLEDGMENT}

This research was supported by Jember Regency Government. We thank our colleagues from Politeknik Negeri Jember who provided insight and expertise that greatly assisted the research.

\section{REFERENCES}

[1] N. DM, "The performance of competitiveness commodities agroindustry indonesia sector," Bus. Econ. J., vol. 19, no. 1, pp. 37-48, 2012.

[2] A. S, "Institutional Farmers: The role and the capacity development strategy," J. Soc. Econ. Agric. Agribus., vol. 7, no. 2, pp. 102-109, 2011.

[3] N. D. Wahyono and M. M. D. Utami, "THE DEVELOPMENT STRATEGY OF NATIVE CHICKEN (AYAM KAMPUNG) INDUSTRY IN JEMBER REGENCY USING SWOT ANALYSIS," UNEJ e-Proceeding, pp. 47-53, 2018.

[4] Sulistyastuti and Ratih, "Dynamics of Small and Medium Enterprises (UKM) Analysis of Regional Concentration of UKM in Indonesia 1999 - 2001, $J$. Dev. Econ., vol. 9, 2004.

[5] Supriatna and Aminah, "Analysis of Luwak Coffee Business Development Strategy," J. Manag. Organ., vol. 5, no. 2, pp. 227-243, 2014.

[6] F. Retnoningsih, I. B. Suryawardani, and P. N, "Selection of Priority for Processed Chocolate Marketing Strategies Based on the Analytical Hierarchy Process Method," E-Journal Agribus. Agrotourism, vol. 5, no. 1, 2016.

[7] A. Rahmana, I. Yani, and O. Riena, "Development Strategy for Small and Medium Enterprises in the Manufacturing Industry Sector," vol. 13, no. 1, pp. 14-21, 2012.

[8] T. Saaty, Decision Making for Leaders. Jakarta: PT. Bustaman Binaman Presindo, 1993. 